
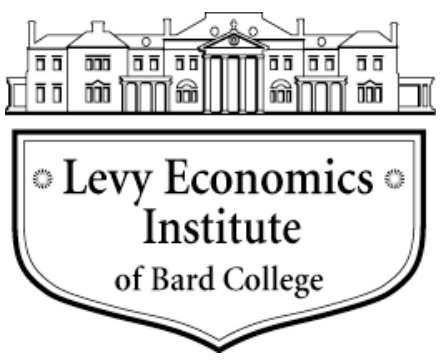

Working Paper No. 776

\title{
Fiscal Policy and Rebalancing in the Euro Area: A Critique of the German Debt Brake from a Post-Keynesian Perspective*
}

\author{
by \\ Eckhard Hein \\ Achim Truger \\ Berlin School of Economics and Law \\ Institute for International Political Economy (IPE) Berlin
}

September 2013

\begin{abstract}
* For a more extensive discussion of the future of German fiscal policies in the European context, see Hein and Truger (2014). Correspondence: Berlin School of Economics and Law, Badensche Str. 50-51, 10825 Berlin, Germany.E-mail: eckhard.hein@hwr-berlin.de; truger@hwr-berlin.de.
\end{abstract}

The Levy Economics Institute Working Paper Collection presents research in progress by Levy Institute scholars and conference participants. The purpose of the series is to disseminate ideas to and elicit comments from academics and professionals.

Levy Economics Institute of Bard College, founded in 1986, is a nonprofit, nonpartisan, independently funded research organization devoted to public service. Through scholarship and economic research it generates viable, effective public policy responses to important economic problems that profoundly affect the quality of life in the United States and abroad.

\author{
Levy Economics Institute \\ P.O. Box 5000 \\ Annandale-on-Hudson, NY 12504-5000 \\ http://www.levyinstitute.org
}

Copyright (C) Levy Economics Institute 2013 All rights reserved

ISSN 1547-366X 


\begin{abstract}
The German debt brake is often regarded as a great success story, and has therefore served as a role model for the Euro area and its fiscal compact. In this paper we fundamentally criticize the debt brake. We show that (1) it suffers from serious shortcomings, and its success is far from certain even from a mainstream point of view; (2) from a Post-Keynesian perspective, it completely neglects the requirements for fiscal policies of member-countries in a currency union and will prevent fiscal policy from contributing to the necessary rebalancing in the Euro area; and (3) alternative scenarios, which could avoid the deflationary pressures of the German debt brake on domestic demand and contribute to internally rebalancing the Euro area, are extremely unlikely, as they would have to rely on unrealistic shifts in the functional income distribution and/or investment and savings behavior in Germany.
\end{abstract}

Keywords: Fiscal Policy; Rebalancing; Functional Income Distribution; Debt Brake; Germany; Euro Area

JEL Classifications: E25, E61, E62, E64, E65, H62, H63 


\section{INTRODUCTION}

The German debt brake seems to be a great success story. Germany incorporated the debt brake into its Constitution back in the summer of 2009, just before the onset of the Euro crisis. According to the brake, from 2020 onwards the structural government deficit must not be higher than 0.35 percent of GDP. And, in fact, the debt brake seems to work. After the stimulus packages to counter the recession in 2009 and 2010 the German fiscal exit was quick and apparently smooth: the 2010 general government budget deficit of 4.1 percent of GDP was turned into a small surplus of 0.1 percent of GDP within only two years by 2012, and also the structural budget balance showed a slight surplus. At the same time the German economy had recovered very quickly from the crisis with comparatively low and even decreasing unemployment. When most European Union (EU) governments pledged at the end of 2011 to introduce stricter regulations on public debts and deficits, where possible incorporating them into the Constitution, this resulted primarily from an acute sense of panic in the face of the continuing escalation of the euro crisis. But the fact that they resorted to the German approach of constitutionally fixed debt brakes certainly also had something to do with the apparent success of the German example.

In our view, however, this interpretation is flawed for several reasons. On the one hand - even without questioning mainstream views on fiscal policies and public debt - the debt brake suffers from conceptual flaws. In addition, it is far too early to consider it a success because it has only been in place for a few years and under quite favourable macroeconomic circumstances. On the other hand, and more importantly, from a Post-Keynesian perspective the whole concept of the debt brake lacks a convincing justification.

Firstly, restricting fiscal deficits and government debt ignores basic macroeconomic accounting identities and implicitly demands corresponding reactions of the other macroeconomic sectors, the private sector and the external sector, if depressing short- and long-run effects on aggregate demand, output and employment are to be avoided. Secondly, imposing strict 'one size fits all' restrictions of government deficits and debts on the member countries of a currency union as heterogeneous as the Euro area deprives member countries of the most important tool left to counter asymmetric shocks in the short run and to balance current accounts within the currency union in the long run. Therefore, thirdly, the introduction of debt brakes à la Germany carries severe risks for future macroeconomic developments, in Germany and in the Euro area. Under realistic parameter constellations, it imposes severe deflationary pressure on domestic demand in Germany, and in the other countries which (have 
to) follow this role model. It is difficult to see how the concomitant lack of domestic demand in the Euro area could be remedied by increasing external demand from the rest of the world. The debt brake prevents the internal rebalancing of current account imbalances within the Euro area, and finally, it prevents adequate fiscal responses in Euro area member countries and thus also in Germany - in the face of the current and of future cyclical downturns or periods of prolonged stagnation.

In order to show this, the paper is organised as follows. In Section 2, after a brief introduction of its main characteristics, we show that even from a mainstream point of view the debt brake suffers from serious shortcomings and that its success is far from certain. Section 3 presents a Post-Keynesian functional finance view on budget deficits and rebalancing in the Euro area. Section 4 briefly spells out the requirements for German fiscal policies derived from this view and demonstrates that the debt brake prevents German fiscal policy from fulfilling them. In Section 5 we show that alternative scenarios which could avoid the deflationary pressures of the German debt brake on domestic demand and contribute to internally rebalancing the Euro area are extremely unlikely as they would have to rely on unrealistic shifts in the functional income distribution in favour of the labour income share and/or in investment and savings behaviour in Germany. Section 6 summarises and concludes.

\section{THE GERMAN DEBT BRAKE: BASIC CHARACTERISTICS AND PROBLEMS EVEN FROM A MAINSTREAM PERSPECTIVE}

The debt brake written into Germany's Constitution in 2009 is essentially comprised of three elements. A structural component imposes strict limits on structural government deficits 0.35 percent of GDP for the federal level (the Bund) and 0.0 percent for the federal states (the Länder). The cyclical component increases or decreases these limits according to the economy's cyclical position. An exception clause, finally, permits the limits to be transgressed in exceptional circumstances. The transitional periods for complying with the limits on structural deficits have been fixed as follows: 2016 for the Bund and 2020 for the Länder. In addition, the debt brake provides for consolidation aid for five Länder (Berlin, Bremen, Saarland, Saxony-Anhalt, and Schleswig-Holstein) in financial distress under strict conditions regarding consolidation efforts.

Although in German economic expert circles the debt brake is often treated as beyond any doubt, it poses serious problems even from a more mainstream perspective. 
Firstly, the capping of structural government net borrowing at 0.35 percent of GDP for the Bund and the banning of all structural deficits by the Länder is completely arbitrary. It means that with an average annual growth in nominal GDP of 3 percent, the national debt-toGDP ratio will converge to just 11.7 percent in the long run. We do not contest that there are some mainstream arguments for some ceiling on the debt ratio. But - if anything - recent empirical research indicates that the critical threshold beyond which government debt might harm growth is above 80 or even 90 percent of GDP. ${ }^{1}$ By imposing artificial limits on what has traditionally been the safest form for financial investment, the debt brake will instead deprive capital markets of a crucial stability anchor and a vital benchmark. It is unclear in which financial assets, and to which countries, the traditionally high excess saving and the accumulated financial wealth of the German private sector (including the assets of private pension schemes) will be diverted in the future, but it is likely that this measure will contribute to more unstable financial markets.

Secondly, the debt brake is in opposition to a broadly accepted economic yardstick for the scale of national deficits - the Golden Rule - and thus turning its back on 60 years of theoretical common sense. The Golden Rule, or the 'pay-as-you-use' principle, as a growthoriented rule for government deficits permits structural deficits to be equivalent to net public investment. The idea behind the rule obviously is to involve several generations in financing public capital accumulation, since future generations will benefit in terms of greater prosperity from the productive investments made today (see Musgrave 1959). It is true that the old rules governing borrowing by both the Bund and the Länder in the German Constitution were imperfect: They were unable to distinguish between gross and net investment and, moreover, they failed to include all forms of economically relevant investment. However, there was almost no discussion around a more workable definition or an estimate of depreciation - just as there was not with the Maastricht criteria or the European Stability and Growth Pact (SGP) with the result that the incentives for governments to invest in the public capital stock have been seriously harmed.

Thirdly, the impact of the debt brake is, of course, critically dependent on its precise technical design and on how the underlying cyclical adjustment method and the applicable budget sensitivities are selected. Although the Bund has already opted for the method used by

\footnotetext{
${ }^{1}$ See Reinhart and Rogoff (2010) as the most prominent of the studies. However, as Nersisyan and Wray (2010) have convincingly demonstrated, such studies suffer from serious methodological shortcomings and should, therefore, not be taken as a guideline for economic policy. The doubts as to the original contribution by Reinhart and Rogoff have been reinforced very much by the discovery by Herndon et al. (2013) of major flaws in the underlying calculations.
} 
the European Commission as part of its own monitoring of member states' budgets, the decision as to the details of implementation is taken by the Ministries for Finance and Economics, so the mechanism is anything but transparent and is open to manipulation. As far as the Länder are concerned, for many of them detailed implementation is still an open question (see Deutsche Bundesbank 2011 and 2012). And since, under Article 109 of the Constitution, there is considerable scope for local input; Germany could by 2020 have no fewer than 17 different debt brakes, one for the Bund and one for each of the Länder, all with widely differing designs and effects.

Fourthly, and finally, the debt brake will ultimately exert a pro-cyclical effect on the economy because of the way the commonly used cyclical adjustment methods work and it will therefore destabilise economic development. During times of downturn, too much consolidation will be required while, conversely, too little will be required during periods of recovery. Currently, German fiscal policy seems to be in a very comfortable position because in the aggregate for the general government sector the structural balance for 2012 as calculated by the EU Commission showed a slight surplus (Figure 1). Actually, it may seem that Germany is outperforming the target even 8 years before the final deficit limits set in.

Figure 1

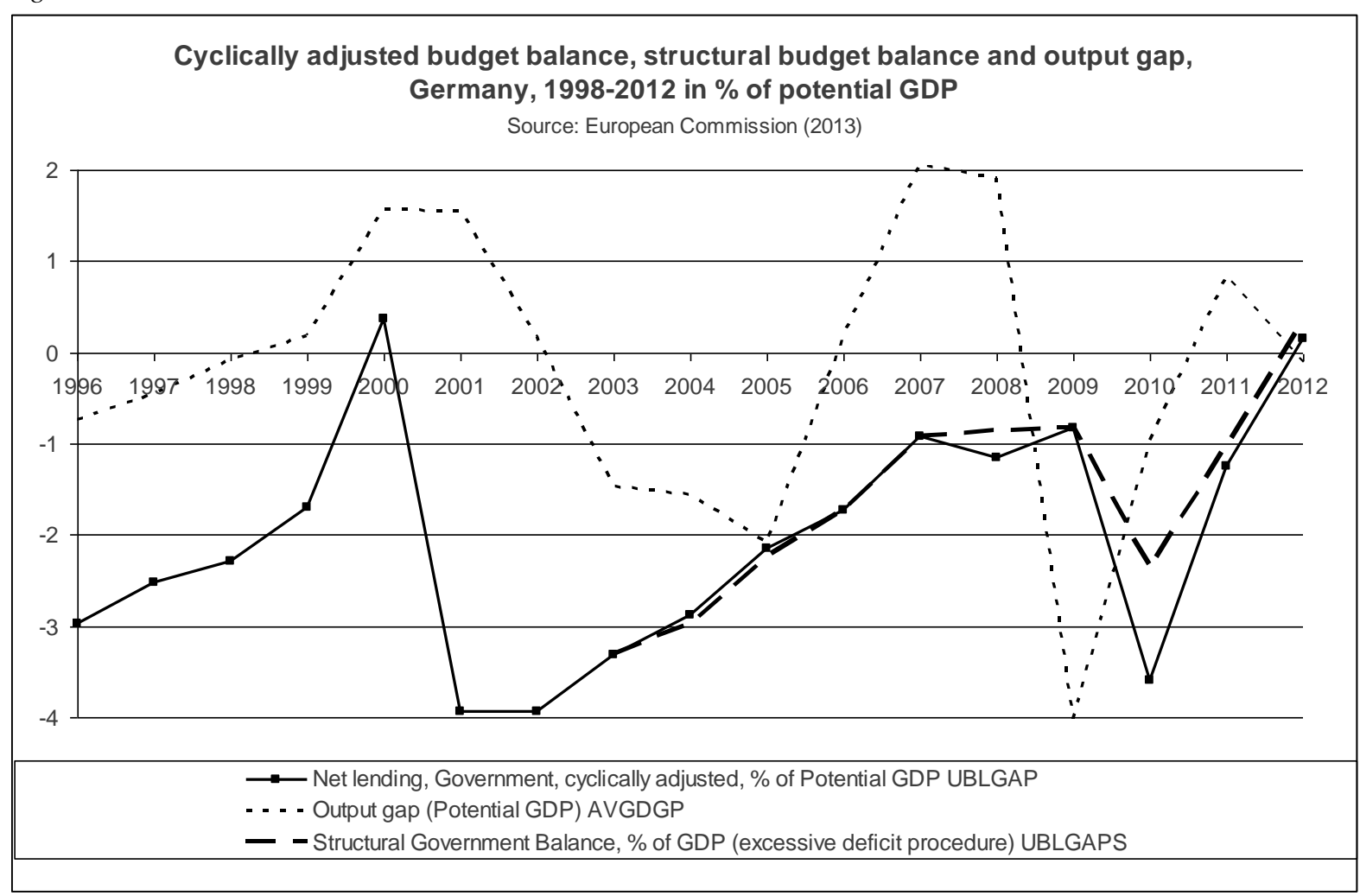


However, it is well known, that the structural balance will be affected by the cyclical conditions of the economy as by the very nature of the method of cyclical adjustment, potential output and structural budget balances are sensitive to variations in actual output. In fact it turns out that a substantial part of the structural consolidation success in the German budgets is based on 'presents' made by the endogeneity of the structural government balance included in the applied method of calculation. For example, from its Spring 2010 to its Winter 2013 forecast the European Commission revised its forecast of actual real GDP for the year 2012 by +2.7 percentage points. However, the estimated output gap increased only by 1.9 percentage points (European Commission, 2010 and 2013). This means that the estimate of potential output was increased by 0.8 percentage points due to the unexpectedly strong upswing. Multiplying this number with the budget sensitivity of 0.51 for Germany gives a 'present' in terms of structural consolidation of 0.4 percent of GDP (Rietzler et al. 2013: 9). Furthermore, there is evidence that the budget sensitivity used - especially with respect to taxes that are particularly relevant for the federal and the federal states' budgets - is much too small. Calculations with data from the German group of tax revenue forecasters show that from the Spring 2010 tax revenue forecast to the latest forecast, the general government tax revenue for 2011 was revised upwards by 59 billion euros ( 2.3 percent of GDP) after controlling for changes in the tax code. The forecast for real GDP over the same period was raised by 4.1 percentage points. This implies a sensitivity of tax revenues to real GDP of 0.55 ; however, the European Commission as well as the German federal government use a value of only 0.3 in their method of cyclical adjustment. Therefore, recent structural consolidation in Germany can be explained, to an important degree, by endogenous technical revisions of potential GDP as a reaction to upward revisions of actual GDP and tax revenue (Rietzler et al. 2013: 9-10).

Therefore, the future of Germany's fiscal policy will depend to a large degree on its future cyclical conditions. If the German economy continues to see more or less satisfactory growth rates without any major slowdown then the structural consolidation improvements will continue even in the absence of major consolidation programmes. If, however, the German economy will suffer from a major recession or a prolonged period of stagnation then the whole process of pro-cyclical revisions of potential GDP and with it of the structural budget balance will be reversed. Then it will start working in the opposite direction of a cyclical deterioration of the structural balance that would - given the fixed deadlines for the structural deficit limits - almost inevitably lead to pro-cyclically restrictive fiscal policies just as they were observable in the period from 2001 to 2005 (Hein and Truger 2007b). 


\section{FISCAL POLICIES IN A CURRENCY UNION - A POST-KEYNESIAN PERSPECTIVE}

Fiscal policy has a major role to play in a Post-Keynesian macroeconomic policy assignment in general and has to be carefully coordinated with the other areas of macroeconomic policy making, i.e. monetary policy and wage policy (Hein and Stockhammer, 2010; Arestis, 2011c, 2013). This is particularly true in a currency union such as the Euro area, where monetary policies are centralised and the base interest rate, the main tool of the central bank, cannot be geared towards the requirements of individual countries or regions, where wage policies are difficult to coordinate across the currency area, and where fiscal policies are still the responsibility of the national governments of the member countries. In this section we will outline a benchmark for fiscal policies under these conditions and in the context of the coordination of the macroeconomic policy mix as a whole, in particular with an eye to overcoming the current euro crisis. ${ }^{2}$

Regarding monetary policies, in contrast to the New Consensus Macroeconomics, ${ }^{3}$ the Post-Keynesian approach (Hein and Stockhammer, 2010) recommends that the central bank's interest rate policies should abstain from attempting to fine tune unemployment in the short run and inflation in the long run. Instead, central banks should generally focus on targeting low real interest rates in credit and financial markets in order to avoid unfavourable cost and distribution effects on firms and workers. ${ }^{4}$ A slightly positive long-term real rate of interest, below the long-run rate of productivity growth or the long-run growth rate of real GDP, seems to be a reasonable target. Rentiers' real financial wealth will be protected against inflation, but redistribution of income in favour of the productive sectors and at the expense of the rentiers will take place, which should be favourable for real investment, employment and growth. Furthermore, the central bank has to act as a 'lender of last resort' in periods of liquidity crisis, not only for the private and public banking sector, but also for the governments. As the recent euro crisis has shown, this is extremely important for the member countries of a currency union. If the central bank unconditionally guarantees the public debt of the member countries of a currency area, these countries can go into debt in their 'own currency' and can avoid excessive risk premiums imposed by rentiers in financial markets. Different

\footnotetext{
${ }^{2}$ See Hein (2012, Chapter 8) and Hein et al. (2012) for an analysis of the euro crisis and the role of the internal current account imbalances.

${ }^{3}$ For the New Consensus Macroeconomics (NCM) see Goodfriend and King (1997), Clarida et al. (1999) and Woodford (2003), and for detailed critiques of the NCM and its application in economic policy making in the EU, see Arestis (2009, 2011a, 2011b), Arestis and Sawyer (2004a), and Hein and Stockhammer (2010).

${ }^{4}$ See Rochon and Setterfield (2007) for a review of Post-Keynesian suggestions regarding the 'parking it' approach towards interest rate policies of central banks and the rate of interest central banks should target.
} 
institutional solutions for this are possible and have been suggested for the European Central Bank (ECB) and the Euro area (see e.g. Hein 2013 or Palley 2011). What is important for the purpose of the present paper is that the central bank of the currency union guarantees the public debt of the member countries without limitations and thus allows member countries to fulfil the fiscal policy tasks which we will specify below.

Incomes and wage policies should take care of nominal stabilisation, i.e. stable inflation at some policy determined target rate. Since accelerating inflation is always the result of unresolved distribution conflicts, distributional claims of workers, firms, rentiers, government, and the external sector have to be consistent with each other. Therefore, if the claims of the other actors are constant, as a guideline nominal wages in each country should rise according to the sum of long-run growth of labour productivity in the relevant country plus the inflation target for the currency union as a whole. On the one hand, this would keep distributional shares in each country constant, and on the other hand, this would mean that each country would obtain the target rate of inflation in the medium to long run. Following such a policy would, therefore, prevent 'beggar-thy-neighbour' strategies. In order to achieve the targets for nominal wage growth, a high degree of wage bargaining co-ordination at the macroeconomic level, and organised labour markets with strong trade unions and employer associations seem to be a necessary condition. ${ }^{5}$ Government involvement in wage bargaining may be required, too. In particular, minimum wage legislation and a minimum wage following the wage norm pointed out above, especially in countries with highly deregulated labour markets and increasing wage dispersion, will be helpful for nominal stabilisation at the macroeconomic level, apart from its usefulness in terms of containing wage inequality. Deregulation of the labour market, weakening labour unions, and reductions in the reservation wage rate by means of cutting unemployment benefits, however, will be detrimental to nominal stabilisation and will rather impose deflationary pressures on the economy.

With the assignment of monetary and wage policies as in the previous paragraphs, fiscal policies will have to take the responsibility for real stabilisation, full employment and also a more equal distribution of disposable income. This has the following implications. By definition the excess of private saving (S) over private investment (I) at a given level of economic activity has to be absorbed by the excess of exports (X) over imports (M) (including the balance of primary income and the balance of income transfers, thus the current account balance) plus the excess of government spending $(\mathrm{G})$ over tax revenues $(\mathrm{T})$ :

\footnotetext{
${ }^{5}$ See Hein (2002) for a review of the related theoretical and empirical literature.
} 


$$
\mathrm{S}-\mathrm{I}=\mathrm{X}-\mathrm{M}+\mathrm{G}-\mathrm{T} .
$$

Therefore, with balanced current accounts within the currency area, government deficits $(\mathrm{D}=$ $\mathrm{G}-\mathrm{T}$ ) have to permanently take up the excess of private saving over private investment in each country in order to assure a high desired level of employment:

$$
\mathrm{D}=\mathrm{G}-\mathrm{T}=\mathrm{S}-\mathrm{I} \text {. }
$$

This is, of course, the 'functional finance' view, pioneered by Lerner (1943). ${ }^{6}$ As is well known from Domar (1944), a constant government deficit-GDP ratio (D/Y) with a constant long-run GDP growth rate (g) will make the government debt-GDP ratio (B/Y) converge towards a definite value. A constant government debt-GDP ratio $(\mathrm{B} / \mathrm{Y})$ requires that government debt and GDP grow at the same rate:

$$
\mathrm{g}=\frac{\Delta \mathrm{B}}{\mathrm{B}}=\frac{\Delta \mathrm{Y}}{\mathrm{Y}} .
$$

Since the government deficit is $\mathrm{D}=\mathrm{G}-\mathrm{T}=\Delta \mathrm{B}$, it follows that:

$$
g=\frac{D}{B}=\frac{D / Y}{B / Y}
$$

and hence:

$$
\frac{\mathrm{B}}{\mathrm{Y}}=\frac{\mathrm{D} / \mathrm{Y}}{\mathrm{g}}
$$

Therefore, there will be no problem of accelerating public debt-GDP ratios if governments follow the functional finance view. Furthermore, if the central bank targets low interest rates falling short of GDP growth and hence of tax revenue growth - and intervenes in government bond markets such that low interest rates are obtained, government debt service will not mean a redistribution in favour of the income share of rentiers. This underlines the importance of appropriate policy coordination, here between monetary and fiscal policies.

On average over the cycle, with the average net tax rate (including net social transfers) in each member country given, as a first approximation, the government deficits in each of the countries would have to be roughly equal to the excess of private saving over private investment in the respective country. This would mean that the current accounts are roughly balanced at a high level of aggregate demand and employment, and GDP growth is close to what Thirlwall $(1979 ; 2002$, Chapter 5) called the 'balance of payments constrained growth rate' of the individual country. In Hein et al. (2012) we have also argued that deviations from this norm should be accepted, if they are associated with long-run productivity catching-up processes, provided that stable long-run financing mechanisms are established within the

\footnotetext{
${ }^{6}$ See also Arestis and Sawyer (2004b).
} 
currency union. In this case fiscal policies in high growth catching-up countries would not have to dampen aggregate demand in order to achieve a balanced current account and could thus accept current account deficits, whereas fiscal policies in the mature low growth countries would not have to aim at completely eradicating current account surpluses by means of stimulating the economy.

Permanent government deficits should be directed towards public expenditure (including public employment), providing the economy with public infrastructure, and public education in order to promote structural change towards an environmentally sustainable longrun growth path. Apart from this permanent role of government debt, which also supplies a safe haven for private saving and thus stabilises financial markets, counter-cyclical fiscal policies - together with automatic stabilisers - should stabilise the economy in the face of aggregate demand shocks. At the same time, progressive income taxes, relevant wealth, property and inheritance taxes, as well as social transfers, should aim at redistributing income and wealth in favour of low income and low wealth households. On the one hand, this will reduce excess saving at full employment and thus stabilise aggregate demand - without generating problems of unsustainable indebtedness for private households. Progressive income taxation and relevant taxes on wealth, property and inheritance thus also reduce the requirements for government deficits. On the other hand, redistributive taxes and social policies will improve automatic stabilisers and thus reduce fluctuations in economic activity.

In a situation of massive current account imbalances, as they have developed in the Euro area from 1999 until 2008/9, some deviations from the norms for fiscal and wage policies outlined above are required in order to contribute to internally rebalancing the currency union. Current account surplus countries should use more expansionary fiscal policies to increase domestic demand such that current account surpluses are reduced and even temporary current account deficits might arise - and the actual growth rate adjusts towards and even exceeds the balance of payments constrained growth rate temporarily. This would lift external growth for the current account deficit countries and would thus allow these countries to reduce their deficits. For a transitional period, the current account surplus countries should also increase their rates of inflation relative to the rates of inflation in the current account deficit countries. Nominal wage growth in the surplus countries should therefore exceed the sum of national productivity growth plus the Euro area inflation target during the adjustment process.

The major task for the current account deficit countries is to improve their balance of payments constrained growth rates. This means, on the one hand, to contribute to a reduction 
of the inflation differentials with respect to the surplus countries, by means of nominal wage growth below the sum of national productivity growth plus the inflation target. The inflation target for the currency area as a whole should allow for room of manoeuvre and prevent the risk of deflation in these countries during the process of adjustment. Fiscal policies in a transition period should undercut the norm we have outlined above. However, more importantly these countries have to increase the income elasticity of demand for their exports and to reduce the income elasticity of demand for imports by means of industrial, structural and regional policies; this means they have to improve their non-price competitiveness.

\section{FUNCTIONAL FINANCE AND REBALANCING - REQUIREMENTS FOR GERMAN FISCAL POLICY IN THE EURO AREA}

The German sectoral financial balances display high surpluses of the private sector, that is high excesses of private saving over private investment, which, on average between 1999 and 2007, to much less than 50 percent were mopped up internally by public sector deficits and therefore required high external sector deficits to be maintained, i.e. high German current account surpluses (Figure 2). The less pronounced private sector surpluses of the initial Euro are (EA-12) as a whole were mainly used internally by public sector deficits and only small external sector deficits and thus current account surpluses of the EA-12 arose (Figure 3). These findings imply that the major counterparts to the German current account surpluses were to be found within the Euro area, with one major example being Spain (Figure 4). In Germany, the private sector surplus was generated by the private household sector - on average over the period 1999-2007 the financial balance of the corporate sector was slightly negative. However, taking a look at the development over time reveals that since 2002 the corporate sector balances have been positive, too (Figure 2). 
Figure 2

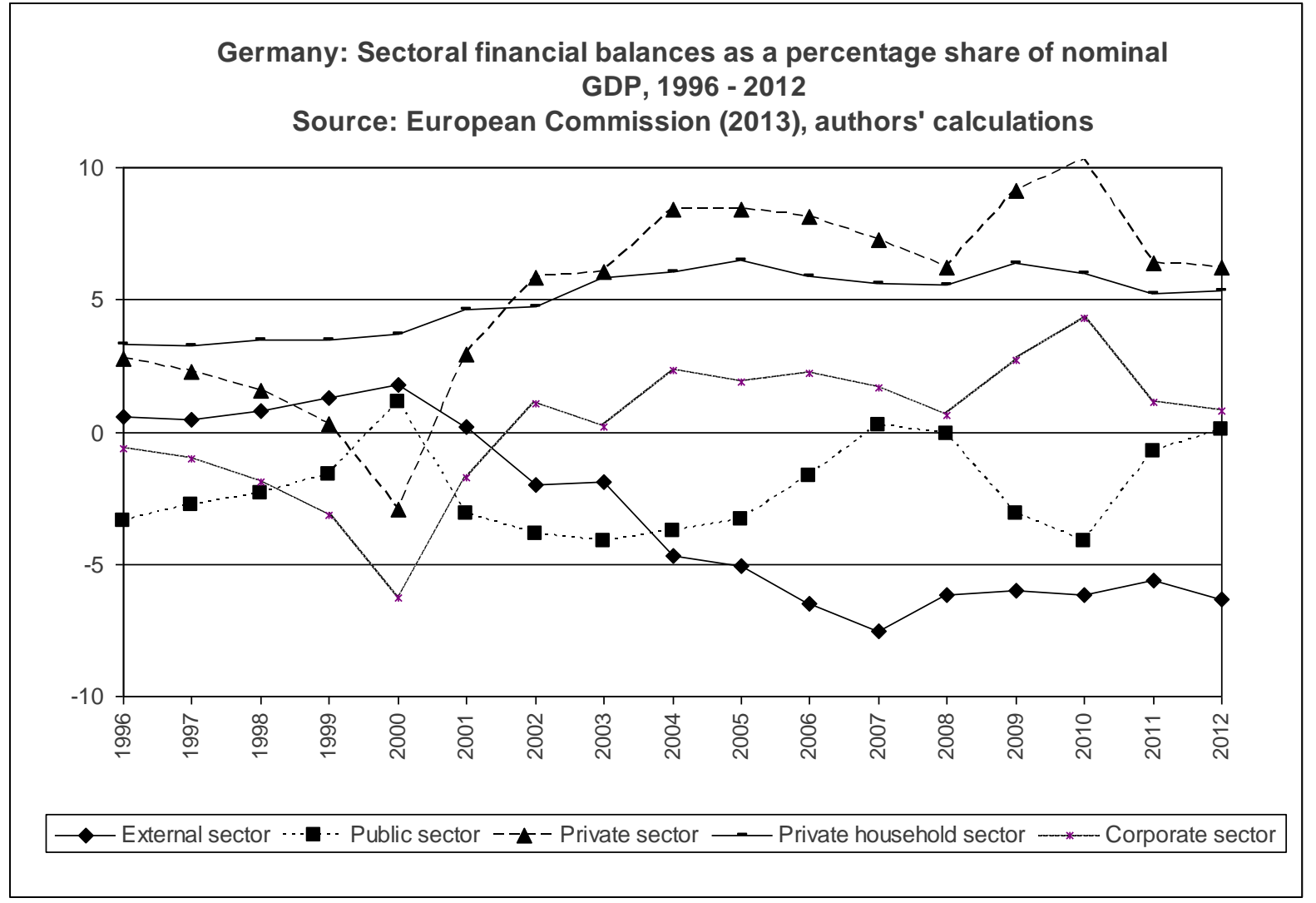

Figure 3

EA 12: Sectoral financial balances as a percentage share of nominal GDP, 1996 - 2012

Source: European Commission (2013), authors' calculations

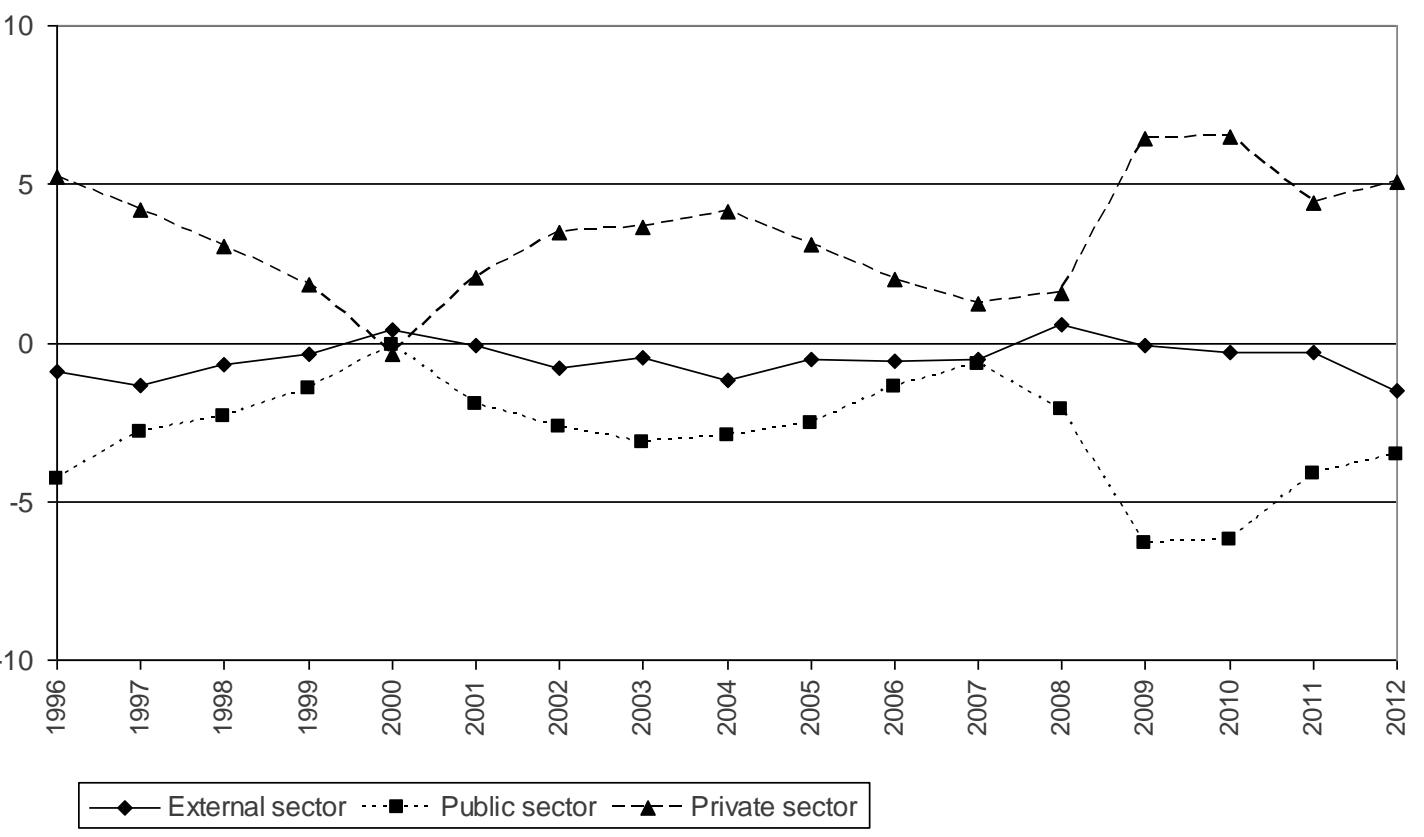




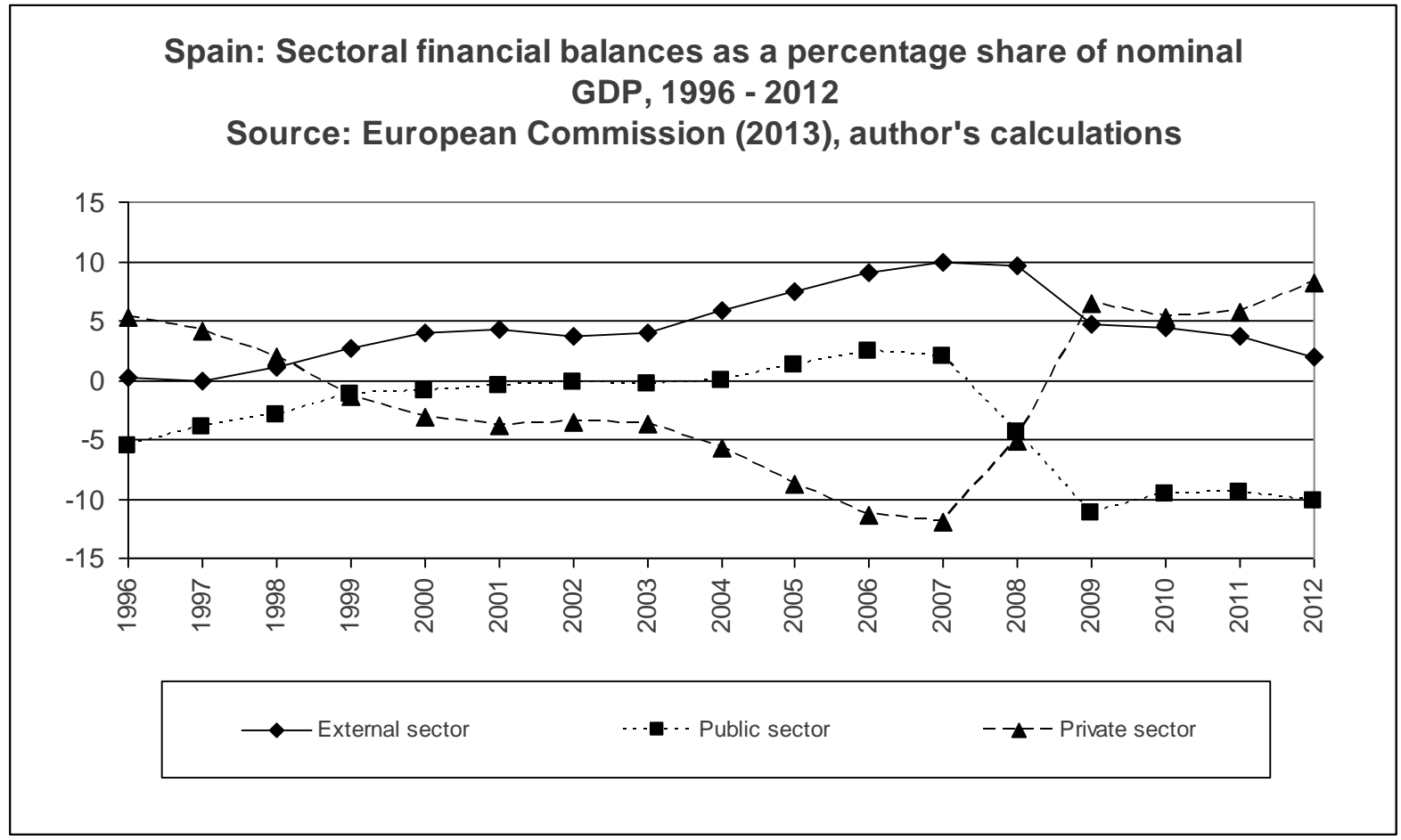

Therefore, taking a long-run perspective, fiscal deficits in Germany fell short of the norm for the members of a currency union outlined in the previous section. But also in a short-run perspective, German fiscal policies were overly restrictive. For example, from 2002 to 2005 the structural budget balance was substantially improved and fiscal policies were thus restrictive although the output gap fell and the economy was in a downturn (Figure 1). Restricted by the European Treaties and the Stability and Growth Pact, German fiscal policies neither compensated for private sector surpluses in the medium to long run, and did thus not contribute to generating sufficient domestic demand and to avoiding current account surpluses. Nor were fiscal policies sufficiently stabilising in the short-run cyclical perspective.

The first best solution to these problems would be to follow the rules and norms for fiscal policies in member countries of a currency union, which we have outlined in Section 3 of this paper. This would mean that the medium- to long-run fiscal deficits should be roughly equal to the excess of private saving over private investment and thus to the private sector surplus in the respective economies, generating high levels of domestic demand securing full employment. Since in Germany the average private sector financial balance surplus over the period 1999-2007 amounted to more than 5 percent of GDP and was again in that region in 2011 and 2012 (Figure 2), this would require fiscal deficits around that level in order to balance the current account in the long run. However, such deficits would clearly violate the German debt brake and the regulations of the Fiscal Compact and would therefore require the 
abandonment of these regulations. This is extremely difficult to obtain, because the debt brake is in the German Constitution and a revision would require a two-thirds majority in the German parliament. And also a revision of the Fiscal Compact, although not impossible, will be difficult to obtain, too. Therefore, we look at alternative strategies in the following section.

\section{SATISFACTORY GROWTH AND REBALANCING UNDER THE DEBT BRAKE - IS THERE A WAY OUT?}

As a reform of fiscal policy along the functional finance lines just sketched seems hardly feasible politically, in this section we discuss a potential second best solution, which would have to accept the limitations imposed on government deficits and debt and would therefore have to look for other ways of rebalancing the Euro area economies without crushing them. ${ }^{7}$ Obviously, such measures would have to address the private sector financial balances and would have to adjust these balances in line with the two constraints, that is a government and an external financial balance each close to zero. In the case of Germany, this would mean stimulating private investment and increasing private consumption thereby reducing private saving. In order to include the distributional implications of such an approach, we start with equation (1), distinguish the propensities to save from profits $\left(\mathrm{s}_{\Pi}\right)$ and from wages $\left(\mathrm{s}_{\mathrm{W}}\right)$, and denote the share of profits in gross national income as $\mathrm{h}$ and the wage share accordingly as 1 h. ${ }^{8}$ Equation (1) thus turns into:

$$
\mathrm{S}=\mathrm{s}_{\mathrm{W}}(1-\mathrm{h}) \mathrm{Y}+\mathrm{s}_{\Pi} \mathrm{hY}=\mathrm{I}+\mathrm{X}-\mathrm{M}+\mathrm{G}-\mathrm{T} .
$$

From this equation based on an accounting identity we obtain for the implied profit share, with given propensities to save out of wages and profits:

$$
h=\frac{\frac{I}{Y}-\frac{T-G}{Y}+\frac{X-M}{Y}-s_{W}}{s_{\Pi}-s_{W}} .
$$

Equation (7) can now be used to discuss different scenarios for the investment share in GDP $(\mathrm{I} / \mathrm{Y})$, the government financial balance as a share of GDP $[(\mathrm{T}-\mathrm{G}) / \mathrm{Y}]$, the current account surplus as a share of GDP $[(\mathrm{X}-\mathrm{M}) / \mathrm{Y}]$. We do so in relation to income distribution and hence the profit share in GDP (h), taking into account the restrictions of the German debt brake and the European Fiscal Compact, on the one hand, and the requirement of rebalancing the

\footnotetext{
${ }^{7}$ Different thought experiments concerning the conditions of rebalancing according to the requirements by the SGP have been presented, e.g. by Sawyer (2011), Brecht et al. (2012) and Semieniuk et al. (2012a and 2012b). Despite the differences in the approaches the results are similarly discouraging.

${ }^{8}$ Different from Section 3, the wage share in this section is not corrected to include the labour income of the self-employed. It is, thus, a true wage share and not a labour income share. We have chosen this indicator for distribution, because most of the econometric studies referred to in this section have used the wage share and not the labour income share.
} 
European and the world economy and hence a reduction of the German current account surplus, on the other hand. For these scenarios we need some information about the propensities to save from wages and from profits.

Several recent empirical studies have examined the effects of changes in functional income distribution on aggregate demand, including on Germany (Naastepad and Storm 2007; Hein and Vogel 2008, 2009; Stockhammer et al. 2011; Onaran and Galanis 2012). In the context of these studies the propensities to consume out of profits and out of wages were estimated starting from national account data and using gross profits (including depreciation, retained earnings, interest, dividends, rent) and wages (compensation of employees) before redistribution by the government. The results are thus appropriate for our exercise, which is also at the level of national account data and aggregates. The estimations carried out in these studies, based on annual data ranging from the early 1960s or 1970s to the early 2000s, find differentials between the propensities to save from profits and from wages within the range of 30 percentage points (Hein and Vogel 2008) and 50 percentage points (Onaran and Galanis 2012). On average over these studies the differential is 40 percentage points. Although the estimated differentials between the two propensities are in a rather narrow band, the levels of the saving propensities are widely different. For the propensity to save from wages they vary from 9 percent (Naastepad and Storm 2007) to 46 percent (Hein and Vogel 2008) and for the propensity to save from profits we have values ranging from 48 percent (Naastepad and Storm 2007) to 82 percent (Onaran and Galanis 2012). ${ }^{9}$

In order to base our scenarios on consistent data we have, therefore, chosen to calibrate the propensity to save from wages, using the robust differential of the saving propensities from profits and from wages of 40 percentage points obtained from the econometric studies, together with average data for Germany for the euro period before the crisis, i.e. for the period 1999-2007, taken from the national accounts. Rearranging equation (7), we have calculated the propensity to save from wages as follows:

$$
\mathrm{s}_{\mathrm{W}}=\frac{\mathrm{I}}{\mathrm{Y}}+\frac{\mathrm{X}-\mathrm{M}}{\mathrm{Y}}-\frac{\mathrm{T}-\mathrm{G}}{\mathrm{Y}}-\mathrm{h}\left(\mathrm{s}_{\Pi}-\mathrm{s}_{\mathrm{W}}\right) .
$$

We obtain from this that the propensity to save consistent with the data for the considered period and with the differential in saving propensities from previous econometric studies is very low and only about 5 percent.

\footnotetext{
${ }^{9}$ Onaran and Galanis (2012) only provide the estimated elasticities and the differential in saving propensities. However, the marginal propensities to save out of profits and out of wages can be calculated from the data they provide.
} 
Using equation (7), we have generated five potential scenarios in Table 1, taking into account the requirement of a close to balanced government budget, on the one hand, and the requirement of a balanced or only slightly in surplus current account for Germany, on the other hand. For these scenarios we have applied the propensity to save out of wages, calibrated as explained above, the differential of the propensities to save as obtained from the empirical literature, and the average value for the share of gross fixed investment in nominal GDP in the period 1999-2007 obtained from the national accounts. It should be noted, however, that this is a rather optimistic setting, because the investment share has not yet reached that level again since the crisis: In 2012 the share of investment in GDP was only at 18 percent.

Table 1 Redistribution requirements for the profit/wage share under different scenarios concerning investment, current account and the propensity to save from wages

\begin{tabular}{|c|c|c|c|c|c|}
\hline Scenarios & $\mathbf{A}$ & $\mathbf{B}$ & C & $\mathbf{D}$ & $\mathbf{E}$ \\
\hline $\begin{array}{l}\text { Gross fixed investment as a share } \\
\text { of nominal GDP (I/Y), in percent }\end{array}$ & 18.9 & 18.9 & 18.9 & 21.5 & 18.9 \\
\hline $\begin{array}{l}\text { Current account balance as share } \\
\text { of nominal GDP }[(\mathrm{X}-\mathrm{M}) / \mathrm{Y})] \text {, in } \\
\text { percent }\end{array}$ & 0.0 & -2.0 & 2.0 & 2.0 & 2.0 \\
\hline $\begin{array}{l}\text { Government financial balance as } \\
\text { a share of nominal GDP } \\
{[(\mathrm{T}-\mathrm{G}) / \mathrm{Y}] \text {, in percent }}\end{array}$ & -0.35 & & & & \\
\hline $\begin{array}{l}\text { Propensity to save from wages } \\
\left(s_{W}\right) \text {, in percent }\end{array}$ & 5.0 & 5.0 & 5.0 & 5.0 & 2.5 \\
\hline $\begin{array}{l}\text { Differential between propensity to } \\
\text { save from profits and from wages } \\
\left(\mathrm{S}_{\Pi}-\mathrm{S}_{\mathrm{W}}\right) \text {, percentage points }\end{array}$ & 40.0 & & & & \\
\hline $\begin{array}{l}\text { Required profit share }(\mathrm{h}) \text {, in } \\
\text { percent }\end{array}$ & 35.5 & 30.5 & 40.5 & 47.1 & 46.8 \\
\hline $\begin{array}{l}\text { Average profit share (h) 1999- } \\
2008 \text {, in percent }\end{array}$ & 47.7 & & & & \\
\hline $\begin{array}{l}\text { Required wage share (1-h), in } \\
\text { percent }\end{array}$ & 64.5 & 69.5 & 59.5 & 52.9 & 53.2 \\
\hline $\begin{array}{l}\text { Average wage share (1-h) 1999- } \\
2008 \text {, in percent }\end{array}$ & 52.3 & & & & \\
\hline $\begin{array}{l}\text { Redistribution requirements from } \\
\text { profit share to wage share, } \\
\text { percentage points }\end{array}$ & 12.2 & 17.2 & 7.2 & 0.6 & 1.0 \\
\hline
\end{tabular}

Source: European Commission (2013), authors' calculations.

Scenario A strictly applies the requirements of the German debt brake's -0.35 percent of GDP limit on the government financial balance and a zero current account surplus. In order to make the data match a given level of nominal GDP - and thus to prevent a collapse of the 
German economy - the associated loss in government and foreign demand would have to be compensated by an increase in consumption demand. With given propensities to save from profits and from wages this would require a massive redistribution in favour of wages. The share of gross profits in nominal GDP would have to fall by 12.2 percentage points and the wage share would have to increase accordingly to a level of 64.5 percent in nominal GDP. This has never been achieved in post-World War II German history, where the highest shares of the compensation of employees in nominal GDP were at 56.4 percent in 1981 in West Germany and at 58.7 percent in 1991 in united Germany (European Commission 2013). Scenario B displays an even larger challenge by assuming that in order to support the Euro crisis countries in rebalancing the German economy will at least temporarily have to run a current account deficit of 2 percent of GDP. In this case the necessary redistribution requirement for the wage share would amount to 17.2 percent.

In Scenario C we relax the requirement of a balanced - or even negative - current account and allow for a current account surplus of 2 percent of GDP. In Hein et al. (2012) and Hein (2013) we have argued that in a heterogeneous currency union with catching-up processes of economically less developed members we would not expect current accounts to be exactly balanced even in the longer run. Rather current account surpluses in the mature economies with slower growth and current account deficits in the catching-up countries with higher growth should emerge and should be tolerated. However, to make these processes sustainable, stable financial transfers from surplus to deficit countries would have to be organised. But even if we allow for moderate current account surpluses in Germany, we would still need considerable redistribution, i.e. a reduction of the profit share by seven percentage points and an increase of the wage share to the level of the early 1990s.

Scenarios D and E have been set up in such a way that hardly any redistribution in favour of the wage share is required. In Scenario D an increase in the share of investment in GDP to 21.5 percent provides for the required domestic demand. However, it remains unclear how this could be achieved, given the fact that since 2000 such values have no longer been reached in Germany (European Commission 2013). In united Germany, gross investment shares in GDP reaching or exceeding 21.5 percent were only obtained during the German unification boom in the early 1990s and in the following years until 1994. And in West Germany, one has to go back to the 1960s and 1970s to regularly encounter such high values, whereas the 1980s before unification were already characterised by lower values.

In Scenario E, finally, a decrease in the propensity to save from wages (and with stable differentials also in the propensity to save from profits) by 2.5 percentage points provides the 
required domestic demand compensating for the loss of government and foreign demand. But again it is difficult to see, how such a decline in the propensities to save could be obtained, given the notorious absence of wealth effects in private consumption in Germany and the tendency of precautionary saving to rise in periods of increasing uncertainty, as has already been observed before the recent crisis (Dreger and Slacalek 2007; Klär and Slacalek 2006; van Treeck and Sturn 2012).

These simple calculations based on national accounting identities, including some empirical estimation results on the differentials between the propensities to save from profits and wages, illustrate how difficult a second best solution, respecting the German debt brake and the Fiscal Compact and aiming at preventing 'beggar thy neighbour' policies, will be to achieve in the case of Germany with its notorious private sector financial surpluses. Preventing the government from absorbing these surpluses puts enormous pressure on the rest of the world to accept German current account surpluses and the associated deficit position. If this is to be avoided, either unrealistically optimistic assumptions about future private investment or about behavioural changes with respect to consumption and saving have to be made. Alternatively major redistributions in favour of the wage share lifting it to levels not seen so far in modern German economic history would be required. Of course, instead of focussing exclusively on the functional distribution of market incomes, government redistribution by means of progressive income and wealth taxes and social transfers would have to be applied, too, as supplementary instruments. But the redistribution requirements are immense and will be difficult to achieve politically.

\section{SUMMARY AND CONCLUSIONS}

The German debt brake is often regarded as a big success story and has therefore served as a role model for the Euro area and the Fiscal Compact. In this paper we have fundamentally criticised the debt brake from different perspectives. Firstly, we have shown that it suffers from serious shortcomings and that its success is far from certain even from a mainstream point of view concerning fiscal policy and public debt. Secondly, we have shown that the debt brake completely neglects the requirements for fiscal policies of member countries in a currency union like the Euro area. It will prevent fiscal policy from applying a functional finance approach and from contributing to the necessary rebalancing in the Euro area. Thirdly, we have shown that alternative scenarios which could avoid the deflationary pressures of the German debt brake on domestic demand and contribute to internally rebalancing the Euro area are extremely unlikely as they would have to rely on unrealistic shifts in the functional 
income distribution and/or in investment and savings behaviour in Germany. Therefore, none of these alternatives seem to be realistic options. Germany will, thus, continue to free-ride on external demand and German fiscal policies will contribute to deflationary pressure and imbalances at the European and the global level. 


\section{REFERENCES}

Arestis, P. 2009. "New Consensus macroeconomics and Keynesian critique." In E. Hein, T. Niechoj and E. Stockhammer (eds.), Macroeconomic Policies on Shaky Foundations. Whither Mainstream Economics? Marburg, Germany: Metropolis.

. 2011a. "Keynesian Economics and the New Consensus in Macroeconomics." In E. Hein and E. Stockhammer (eds.), A Modern Guide to Keynesian Macroeconomics and Economic Policies. Cheltenham, UK: Edward Elgar.

- 2011b. "European Economic and Monetary Union Policies from a Keynesian Perspective." In E. Hein and E. Stockhammer (eds.), A Modern Guide to Keynesian Macroeconomics and Economic Policies. Cheltenham, UK: Edward Elgar.

- 2011c. "Fiscal Policy Is Still an Effective Instrument of Macroeconomic Policy." Panoeconomicus, 6 (2), 143-156.

. 2013. "Economic Theory and Policy: A Coherent Post-Keynesian Approach." European Journal of Economics and Economic Policies: Intervention, Papers and Proceedings of Research Network Macroeconomics and Macroeconomic Policies. Forthcoming.

Arestis, P. and Sawyer, M. 2004a. Re-examining Monetary and Fiscal Policy for the $21^{\text {st }}$ Century. Cheltenham, UK: Edward Elgar.

. 2004b. "On Fiscal Policy and Budget Deficits." Intervention. Journal of Economics, 1 (2), 61-74.

Brecht, M., Tober, S., Truger, A. and van Treeck, T. 2012. "Squaring the Circle in Euro Land? Some Remarks on the Stability Programmes 2010-2013." In Papadimitriou, D.B. and Zezza, G. (eds.), Contributions to Stock-flow Modeling. Essays in Honor of Wynne Godley. Basingstoke, UK: Palgrave Macmillan.

Deutsche Bundesbank. 2011. "Die Schuldenbremse in Deutschland - Wesentliche Inhalte und deren Umsetzung." Monatsbericht Oktober 2011, 15-40. Frankfurt a. Main: Deutsche Bundesbank. . 2012. "Zur Entwicklung der Länderfinanzen in Deutschland seit dem Jahr 2005." Monatsbericht Oktober 2012, 31-51. Frankfurt a. Main: Deutsche Bundesbank.

Clarida, R., Gali, J. and Gertler, M. 1999. “The Science of Monetary Policy: A New Keynesian perspective.” Journal of Economic Literature, 37, 1661-1707.

Dreger, C., and Slacalek, J. 2007. "Finanzmarktentwicklung, Immobilienpreise und Konsum." DIW Wochenbericht, 74, 533-536.

European Commission. 2010. "European Economic Forecast - Spring 2010.” European Economy 2. Brussels: European Commission. 
. 2012. "European Economic Forecast - Autumn 2012.” European Economy 7

(Brussels: European Commission).

. 2013. "European Economic Forecast - Winter 2013." European Economy 1

(Brussels: European Commission).

Europeam Council. 2012. Treaty on Stability, Coordination and Governance in the Economic and Monetary Union, 2 March 2012, (Brussels: European Council).

(http://www.consilium.europa.eu/media/1478399/07_-_tscg.en12.pdf.)

Goodfriend, M. and King, R.G. 1997. "The New Neoclassical Synthesis and the Role of Monetary Policy." In B.S. Bernanke and J.J. Rotemberg (eds.), NBER Macroeconomics Annual: 1997. Cambridge, MA: MIT Press.

Hein, E. 2002. "Monetary Policy and Wage Bargaining in the EMU: Restrictive ECB Policies, High Unemployment, Nominal Wage Restraint and Inflation above the Target." Banca Nazionale del Lavoro Quarterly Review, 55, 299-337.

. 2012. The Macroeconomics of Finance-dominated Capitalism - and Its Crisis. Cheltenham, UK: Edward Elgar.

. 2013. "The Crisis of Finance-dominated Capitalism in the Euro Area, Deficiencies in the Economic Policy Architecture and Deflationary Stagnation Policies." Journal of Post Keynesian Economics. Forthcoming.

Hein, E. and Mundt, M. 2012. "Financialisation and the Requirements and Potentials for Wage-led Recovery - a Review Focussing on the G20." ILO Conditions of Work and Employment Series 37. Geneva, Switzerland: ILO.

Hein, E. and Stockhammer, E. 2010. "Macroeconomic Policy Mix, Employment and Inflation in a Post-Keynesian Alternative to the New Consensus Model." Review of Political Economy, 22, 317-354.

Hein, E. and Truger, A. 2007a. "Fiscal Policy and Macroeconomic Performance in the Euro Area: Lessons for the Future." In J. Bibow, and A. Terzi (eds.), Euroland and the World Economy. Global Player or Global Drag? Basingstoke, UK: Palgrave Macmillan.

. 2007b. "Germany's Post-2000 Stagnation in the European Context - A Lesson in Macroeconomic Mismanagement." In P. Arestis, E. Hein, E. Le Heron (eds.), Aspects of Modern Monetary and Macro-economic Policies. Basingstoke, UK: Palgrave Macmillan.

. 2014. "Future Fiscal and Debt Policies: Germany in the Context of the European Monetary Union." In P. Arestis and M. Sawyer (eds.), Fiscal and Debt Policies for the Future. International Papers in Political Economy. Basingstoke, UK: Palgrave Macmillan. Forthcoming.

Hein, E., Truger, A. and van Treeck, T. 2012. "The European Financial and Economic Crisis: Alternative Solutions from a (Post-)Keynesian Perspective.” In P. Arestis and M. 
Sawyer (eds.), The Euro Crisis. International Papers in Political Economy.

Basingstoke, UK: Palgrave Macmillan.

Hein, E. and Vogel, L. 2008. "Distribution and Growth Reconsidered - Empirical Results for Six OECD Countries." Cambridge Journal of Economics, 32, 479-511.

2009. "Distribution and Growth in France and Germany - Single Equation

Estimations and Model Simulations Based on the Bhaduri/Marglin-model." Review of Political Economy, 21, 245-272.

Heinemann, F., Moessinger, M.-D. and Osterloh, S. 2011. "Nationale Fiskalregeln - Ein Instrument zur Vorbeugung von Vertrauenskrisen? " In Federal Ministry of Finance Monthly Report August: 58-66.

Herndon, T., Ash, M., Pollin, R. 2013. "Does High Public Debt Consistently Stifle Economic Growth? A Critique of Reinhart and Rogoff.” PERI Working Paper No. 322, Amherst, Massachusetts: Political Economy Research Institute.

Kalecki, M. 1971. Selected Essays on the Dynamics of Capitalist Economy, 1933-1970. Cambridge, UK: Cambridge University Press.

Klär, E. and Slacalek, J. 2006. "Entwicklung der Sparquote in Deutschland - Hindernis für die Erholung der Konsumnachfrage.” DIW Wochenbericht, 73 (40), 537-543.

Lerner, A. 1943. "Functional Finance and the Federal Debt." Social Research, 10, 38-51.

Musgrave, R.A. 1959. The Theory of Public Finance. A Study in Public Economy, New York: McGraw-Hill.

Naastepad, C.W.M., Storm, S. 2007. “OECD Demand Regimes (1960-2000).” Journal of Post Keynesian Economics, 29, 211-246.

Nersisyan, Y. and Wray, L.R. 2010. "Does Excessive Sovereign Debt Really Hurt Growth? A Critique of This Time Is Different, by Reinhart and Rogoff." Working Paper No. 603 New York: The Levy Economics Institute.

Onaran, Ö. and Galanis, G. 2012. "Is Demand Wage- or Profit-led? National and Global Effects." ILO Conditions of Work and Employment Series 40. Geneva, Switzerland: ILO.

Palley, T. 2011. "Monetary Union Stability: The Need for a Government Banker and the Case for a European Public Finance Authority.” IMK Working Paper 2/2011, (Düsseldorf, Germany: IMK at Hans-Boeckler Foundation).

Reinhart, C. M. and Rogoff, K. S. 2010. "Growth in a Time of Debt." NBER Working Paper 15639 (Washington: NBER).

Rietzler, K., Teichmann, D. and Truger, A. 2013. IMK-Steuerschätzung 2013-2017:

Steuerpolitik am Scheideweg, IMK Report Nr. 81, April, (Düsseldorf, Germany: IMK at Hans Böckler Foundation). 
Rochon, L.-P. and Setterfield, M. 2007. "Interest Rates, Income Distribution And Monetary Policy Dominance: Post-Keynesians and the 'Fair Rate' of Interest." Journal of Post Keynesian Economics, 30, 13-42.

Sawyer, M. 2011. "Progressive Approaches to Budget Deficits.” In Niechoj, T., et al. (eds.) Stabilising an Unequal Economy? Public debt, Financial Regulation, and Income Distribution. Marburg, Germany: Metropolis.

Semieniuk, G., van Treeck, T. and Truger, A. 2012a. "Towards Reducing Economic Imbalances in the Euro Area?” In H. Herr, T. Niechoj, C. Thomasberger, A. Truger and T. van Treeck (eds.), From Crisis to Growth? The Challenge of Imbalances and Debt. Marburg, Germany: Metropolis.

. 2012b. "Nothing learned from the crisis? Some remarks on the Stability Programmes 2011-2014 of the Euro area governments." In J. Jespersen and Madsen, M.O. (eds.), Keynes's General Theory for Today. Cheltenham, UK: Edward Elgar.

Stockhammer, E., Hein, and Grafl, L. 2011. "Globalization and the Effects of Changes in Functional Income Distribution on Aggregate Demand in Germany.” International Review of Applied Economics, 25, 1-23.

Thirlwall, A.P. 1979. "The Balance of Payments Constraint as an Explanation of International Growth Differences.” Banca Nazionale del Lavoro Quarterly Review, 128, 45-53.

. 2002. The Nature of Economic Growth. Cheltenham, UK: Edward Elgar.

Truger, A. and Will, H. 2013. “The German 'Debt Brake': A Shining Example for European Fiscal Policy?” Revue de l'OFCE / Debates and Policies, The Euro Area In Crisis, $127,155-188$.

Van Treeck, T. and Sturn, S. 2012. "Income Inequality as a Cause of the Great Recession? A Survey of Current Debates." ILO Conditions of Work and Employment Series 40. Geneva, Switzerland: ILO.

Woodford, M. 2003. Interest and Prices: Foundations of a Theory of Monetary Policy, (Princeton NJ: Princeton University Press). 